\title{
V3 Avaliação da imunogenicidade do componente caxumba da vacina tríplice viral na rotina do programa nacional de imunizações
}

Eliane Matos dos Santos ${ }^{1}$, Glória Regina da Silva e Sá2, Marilda Mendonça Siqueira ${ }^{3}$, Reinaldo de Menezes Martins ${ }^{1}$, Luiz Antônio Bastos Camacho ${ }^{4}$, Vanessa dos Reis von Doelinger ${ }^{5}$, Maria de Lourdes Sousa Maia ${ }^{1}$

${ }^{1}$ Bio-Manguinhos

2 UNIRIO

3 Instituto Oswaldo Cruz

${ }^{4}$ Escola Nacional de Saúde Pública

${ }^{5}$ Ministério da Saúde

Introdução: O estudo brasileiro realizado em 2007 (Silva \& Camacho, 2011) com a vacina tríplice viral mostrou resultado de soroconversão e TMG mais baixos para o componente caxumba do que os estudos utilizados previamente ao registro da vacina nos Estados Unidos (Usonis et. al., 1998; Usonis et. al., 1999; Gatchalian et. al.,1999). Diante disso, e considerando-se a futura realização de um estudo clínico com a vacina tríplice viral totalmente produzida em BioManguinhos/Fiocruz, a partir de transferência de tecnologia do laboratório GSK, tornou-se fundamental a realização de novos estudos, em busca de se conhecer melhor a imunogenicidade da cepa Caxumba.

Objetivo: Avaliar a imunogenicidade da vacina de sarampo, caxumba e rubéola (tríplice viral), SCR, em crianças de 12 a 23 meses de idade, com ênfase no componente caxumba, pela baixa imunogenicidade encontrada para este componente em estudos anteriores.

Metodologia: Estudo longitudinal, não controlado, conduzido em 150 crianças vacinadas com a vacina SCR, na rotina de três unidades de saúde, localizadas na cidade do Rio de Janeiro, no período compreendido entre 2008 e 2009. Foram realizadas três coletas de amostras sanguíneas: antes da vacinação, após a vacinação (30 a 60 dias) e após a revacinação. A imunogenicidade foi avaliada pela taxa de soroconversão, títulos médios geométricos e razão pós-pré dos títulos.

Resultados: O estudo mostrou $89,5 \%$ de soroconversão (IC 95\%: $83,3 ; 94,0)$ para caxumba, enquanto a bula do produto informa uma soroconversão de $95,5 \%$ (IC 95\%: 94,0; 96,6) para caxumba, usando o mesmo kit diagnóstico e os mesmos critérios de soroconversão. Todas as crianças analisadas soroconverteram para sarampo e rubéola. Amostras de caxumba foram retestadas em um laboratório de referência no exterior e foram concordantes (Kappa ponderado $=0,96$ ) com aquelas obtidas previamente no Laboratório Nacional de 
Referência para Sarampo e Rubéola (IOC/Fiocruz). Após a revacinação, foram alcançados títulos elevados de anticorpos e 100\% de soroconversão contra caxumba.

Conclusão: O presente estudo confirmou a elevada imunogenicidade dos componentes sarampo e rubéola na vacina tríplice viral, mas encontrou uma imunogenicidade mais baixa para o componente caxumba. Os resultados obtidos foram similares a outros estudos conduzidos com metodologias similares, mas foram diferentes dos estudos citados na bula do produto. A principal implicação desses achados é a necessidade de revisão do esquema atual de imunização, recomendado pelo Programa Nacional de Imunizações (PNI/Ministério da Saúde), com a antecipação da segunda dose da vacina SCR, para conferir imunidade elevada contra caxumba durante os primeiros anos de vida.

Palavras-Chave: Vacina Triplice Viral, Imunogenicidade, Caxumba 